Web Jurnal:

http://ejournal.kemenperin.go.id/jli

\title{
The effect of type and method of mordant towards cotton fabric dyeing quality using jengkol (Archidendron jiringa) pod waste
}

\section{Pengaruh jenis dan metode mordan terhadap kualitas pewarnaan kain katun menggunakan limbah kulit jengkol (Archidendron jiringa)}

\author{
S. Sofyan*, F. Failisnur, and S. Silfia \\ Balai Riset dan Standardisasi Industri Padang \\ J1. Raya LIK No. 23 Ulu Gadut Padang 25164, Indonesia \\ *e-mail: sofyantk84@gmail.com
}

\begin{tabular}{l}
\hline ARTICLE INFO \\
\hline History of article: \\
Diterima: \\
19 April 2018 \\
Direvisi: \\
20 Juni 2018 \\
Diterbitkan: \\
28 Juni 2018
\end{tabular}

\section{Keywords:}

dogfruit pod waste;

Archidendron jiringa; mordant;

natural dye;

cotton

\begin{abstract}
Jengkol pod is waste from jengkol (dogfruit). Its extract contains 5.28\% tannin and can be used as a natural dye for textile to add its value. This study was conducted by extracting jengkol pod waste by using water. The treatment of this research is type and method of mordant. The mordant type was $\mathrm{Al}_{2}\left(\mathrm{SO}_{4}\right)_{3}, \mathrm{CaO}$, and $\mathrm{FeSO}_{4}$ and mordant method was conducted using three ways, simultaneous, post, and the combination of both. Dying was applied to cotton fabrics. To find out the effect of each treatment, the colored fabrics measured the strength and darkness of the color. The quality of the colored fabrics was determined by testing the color fastness against washing, acidic and alkaline sweat, light, and rubbing. The results showed that mordant type and method affected the color strength and darkness. The highest color darkness and differences were obtained in the treatment using mordant $\mathrm{FeSO}_{4}$ for all mordant methods. The mordant type and method did not have a significant effect on the color fastness of the fabric. The average of non-mordant fabric (control) has a higher fastness value compared to the colored fabrics. Some treatments have the same color fastness as the control fabric. The $\mathrm{CaO}$ mordant treatment with post and combined mordant method had better color fastness against alkaline sweat and light than controlled fabric treatment.
\end{abstract}

\section{Kata kunci:}

limbah kulit jengkol; Archidendron jiringa; mordan; warna alam; katun

\begin{abstract}
ABSTRAK
Kulit jengkol merupakan limbah yang dihasilkan dari buah jengkol. Ektrak kulit jengkol mengandung tanin sebesar 5,28\% dan dapat dimanfaatkan sebagai pewarna alam tekstil untuk meningkatkan nilai tambahnya. Penelitian dilakukan dengan mengekstrak kulit jengkol menggunakan air. Perlakuan penelitian yaitu jenis dan metode mordan. Jenis mordan yang digunakan adalah $\mathrm{Al}_{2}\left(\mathrm{SO}_{4}\right)_{3}, \mathrm{CaO}$, dan $\mathrm{FeSO}_{4}$. Metode mordan dilakukan dengan tiga cara yaitu simultan, pasca, dan gabungan. Pewarnaan diaplikasikan pada kain katun. Untuk melihat pengaruh masing-masing perlakuan maka kain yang telah diwarnai diukur arah dan ketuaan warnanya. Kualitas kain hasil pewarnaan dilihat dengan menguji ketahanan luntur warna terhadap pencucian, keringat asam dan basa, sinar, dan gosokan. Hasil penelitian menunjukkan bahwa jenis dan metode mordan mempengaruhi arah dan ketuaan warna kain. Ketuaan dan perbedaan warna paling tinggi diperoleh pada perlakuan menggunakan mordan $\mathrm{FeSO}_{4}$ untuk semua metode mordan baik simultan, pasca, dan gabungan. Jenis dan metode mordan tidak memberikan pengaruh yang berarti terhadap ketahanan luntur warna kain. Kain kontrol tanpa mordan rata-rata mempunyai nilai ketahanan luntur yang lebih tinggi dibandingkan dengan kain yang diwarnai. Beberapa perlakuan mempunyai ketahanan luntur warna yang sama dengan kain kontrol. Perlakuan mordan CaO dengan metode mordan pasca dan gabungan mempunyai ketahanan luntur warna terhadap keringat basa dan sinar yang lebih baik dari perlakuan kain kontrol.
\end{abstract}




\section{Introduction}

Jengkol (Archidendron jiringa) is one of the native tropical plants that grow in the lowland of Southeast Asia such as Malaysia, Singapore, Brunei Darussalam, and Indonesia. This plant grows independent to the season. Jengkol is also known as jering in Malaysia, krakos in Cambodia, and niang-yai in Thailand (Barceloux, 2009).

Jengkol contains seed which is consumed in raw form or cooked by society in mIndonesia. Jengkol seed consumed is $56 \%$ will produce jengkol pod which is approximately $44 \%$ wasted and unused (Azima et al., 2017). Total harvested area of jengkol plants in Indonesia in 2014 was $6,678 \mathrm{Ha}$ with a total production of 53,661 tons (Directorate General of Horticulture, 2015). The production will produce 23,611 tons of jengkol pod waste. The amount of the waste will provide great added value if it is used as a more valuable material. One of them is as a source of natural dyes for textile products.

The use of natural dyes for fabric is a nowadays trend and become great demand, although the colors produced are still limited (Samanta and Agarwal, 2009). In quantity, the use of synthetic dyes still dominates but there is a significant increase in the use of textile products with natural dyes (Yusuf et al., 2017). This is because natural dyes have unique colors and natural characteristics that are not produced by synthetic dyes.

Textile products such as batik and hand-woven fabrics with natural dyes are sold at higher prices compared to synthetic colors because of their specific and preferred colors. Some of the advantages of using natural dyes for textiles include biodegradable, nontoxic, eco-friendly, and hypoallergenic (Samanta and Agarwal, 2009).

Study about Jengkol pod as a textile dye has not been widely published. Some of them report on the use of jengkol pod for textile dyes with different treatment variations and objectives. The effect of potassium dichromate and copper (II) mordant on cotton dyeing using the jengkol pod reported by (Muthukumarasamy et al., 2017). The results showed that the highest $\mathrm{K} / \mathrm{S}$ ratio of $1.08 \times 10^{-6}$ was obtained on potassium dichromate mordant using the simultaneous method. (Syahputra et al., 2009) in his study compared jengkol (Pithecollobium jiringa) pod extract, henna (Impatiens balsamina) leaves, and rambutan (Nephelium lappaceum) peel with post mordant method. The most dyestuffs absorbed by cotton were obtained on dyeing with jengkol pod by immersion for 24 hours.

The interactions between mordant types (ferrous sulfate, aluminum sulfate, nickel sulfate, potassium dichromate, and stannous chloride) and mordant method (pre, simultaneous, and post-mordant) have been studied by (Kumaresan, 2014) using dyes from Spathodea campanulata and Cordia sebestena flowers. The fastness and color strength properties were obtained on ferrous sulfate mordant by simultaneous method. Moiz et al., (2010) discussed about the use of aluminum mordant, $\mathrm{CuSO}_{4}, \mathrm{FeSO}_{4}, \mathrm{ZnSO}_{4}, \mathrm{Na}_{2} \mathrm{SO}_{4}$, and $\mathrm{MgSO}_{4}$ using all three mordant method (pre, simultaneous, and post mordant) on wool with tea dye. The use of $\mathrm{CuSO}_{4}$ mordant and post-mordant method provided better color fastness and durability than others.

From the studies, the interaction between mordant type and method with the dye of jengkol pod extract was not studied yet. The objective of this study was to find out the effect of mordant type $\left[\mathrm{Al}_{2}\left(\mathrm{SO}_{4}\right)_{3}, \mathrm{CaO}\right.$, and $\left.\mathrm{FeSO}_{4}\right]$ and mordant methods (simultaneous, post, and combined) towards the dyeing results and quality of colored cotton fabrics.

\section{Method}

The main material was jengkol pod waste taken from local market Pasar Bandar Bandar Padang City. Technical chemical mordants $\left[\mathrm{Al}_{2}\left(\mathrm{SO}_{4}\right)_{3}, \mathrm{CaO}\right.$, and $\mathrm{FeSO}_{4}$ ] from supplier Bratachem. Cotton fabric was the local primisima purchased from fabric traders in Yogyakarta with $100 \%$ cotton specifications. Other supporting materials were detergents and chemical for analysis.

The main equipment for the research was stoves and pans to extract the jengkol pod, scales, and tub for dyeing. The main equipment for testing was spectrophotometer colorscan SS 6200, colorflex Hunter Lab, laundry meter, crockmeter, gray scale and staining scale.

\subsection{Experimental design}

The experiments were conducted by applying different types of mordant, i.e. $\mathrm{Al}_{2}\left(\mathrm{SO}_{4}\right)_{3}, \mathrm{CaO}$, and $\mathrm{FeSO}_{4}$, through different mordanting procedures: simultaneous, post-, and combined mordant, including no-mordant process as a control. Stages of the conducted research were washing fabrics, extracting jengkol pod, dyeing fabrics in extract solution, mordant process, washing of colored fabrics, and a series of dyed fabric evaluations.

\subsection{Fabric washing}

Fabric washing was done by soaking the cloth in a detergent solution $(0.2 \mathrm{~g} / \mathrm{L}$ water $)$, in a hot condition $\left(50-60{ }^{\circ} \mathrm{C}\right)$ for 15 minutes, then rinsed with plain water with normal temperature until clean, finaly it was dried (Sofyan et al., 2015). Fabrics were ready for dyeing.

\subsection{Jengkol pod extraction}

To get the dye extract from jengkol pod, the extraction was conducted by boiling it in water at $100^{\circ} \mathrm{C}$. The jengkol pod was soaked in water with the ratio of $1: 2$. It was boiled until the water was reduced into half, then cooled. The boiled water was filtered through 400 mesh strainer and the extract obtained was ready to use for dyeing process.

\subsection{Dying process}

The extract was heated to a temperature of $50^{\circ} \mathrm{C}$. The fabric that has been washed then was dyed in the solution of the jengkol pod extract. It was then dried 
under shade until the moisture content $25-30 \%$. Then, the mordant process was conducted to the fabric.

Mordant was prepared by making a solution of $7 \%$ $\mathrm{Al}_{2}\left(\mathrm{SO}_{4}\right)_{3}, 5 \% \mathrm{CaO}$, and $3 \% \mathrm{FeSO}_{4}$. The solution was allowed to stand for one night before being used as a mordant solution. After being left overnight, the mordant solution was filtered to separate the insoluble mordant or the impurities (Failisnur and Sofyan, 2014). The obtained solution was ready for the mordant process. Each mordant method was performed with different processes.

The simultaneous mordant method was done by mixing the mordant in the solution of jengkol pod extract. The fabric was dyed in the solution mixture and then dried. Treatment of dyeing was done three times. The post-mordant method was done by dyeing the fabric in the solution of the dye extract first then dried. Immersion in the dye extract was done three times. After the fabric was dry, it was then dyed in the mordant solution. The combined mordant method was done by dyeing the fabric with the dye extract and then after wind dry was done the mordant process. This process was done three times.

The dyed cotton fabric through the mordant process and then washed. The cotton fabric was washed with hot water $70^{\circ} \mathrm{C}$ then continued with regular water $\left(28^{\circ} \mathrm{C}\right)$ several times until the washing water was clear. The fabric was then dried and tested for the quality of the dyed fabric.

\subsection{Evaluations}

\section{a) Identification of tannin and $\mathrm{pH}$ of jengkol pod extract}

Evaluations and tests were performed on the tannin content and $\mathrm{pH}$ of jengkol peel extract before and after the dyeing process. Tannin in jengkol pod extract was determined according to Khasnabis et al., (2015). pH was analysed using $\mathrm{pH}$ meter.

\section{b) Evaluation of colored fabrics}

The color of the fabric was evaluated and tested its quality which includes intensity and color strength, and color fastness. Color strength (K/S) and color coordinate $\left(\mathrm{L}^{*}, \mathrm{a}^{*}\right.$, and $\left.\mathrm{b}^{*}\right)$ were evaluated by using spectrophotometer method CIE-Lab. Evaluations of color fastness properties according to National Indonesia Standard (SNI) include fastness to washing (SNI ISO 105-C06, 2010), rubbing (SNI ISO 105-X11, 2010), light (SNI ISO 105-B01, 2010), and acidic and alkaline sweat (SNI ISO 105-E04, 2010).

\section{Result and discussion}

\subsection{Analysis result of tannin in jengkol pod extract}

Tanin is a complex polyphenolic compound. In the dyeing process, the phenol compounds in the tannins react with the mordant and dyes to form a more stable bond. For that reason, tannin content in the jengkol pod extract was analysed in this study. The results of tannin analysis and $\mathrm{pH}$ of jengkol pod extract are shown in Table 1. Extracts of jengkol pod contained 5.28\% tannin.
The tannin content in the extract that has been used for dyeing has dropped to $4.99 \%$. This is because part of the tannin around $0.29 \%$ has been absorbed into the fabric fibers and reacts with the mordant and dyes lead to formation of complexes with metal ions. The remaining tannins in the extract are still quite high and can be reused for new fabric dyeing. The content of tannin in jengkol pod extract is low compared with other natural dyes. The extraction techniques and solvent used determine the tannin content obtained (Selvam et al., 2015).

Table 1

Analysis result of tannin and $\mathrm{pH}$ of jengkol pod extract.

\begin{tabular}{llll}
\hline \multirow{2}{*}{ No. } & Sample name & \multicolumn{2}{c}{ Analysis result } \\
\cline { 3 - 4 } & \multicolumn{2}{c}{ Tannin (\%) } & $\mathrm{pH}$ \\
\hline 1 & $\begin{array}{l}\text { Extract of jengkol pod } \\
\text { before dyeing }\end{array}$ & 5,28 & 4,87 \\
\hline 2 & $\begin{array}{l}\text { Extract of jengkol pod } \\
\text { after dyeing }\end{array}$ & 4,99 & 4,97 \\
\hline
\end{tabular}

From FTIR analysis result, jengkol pod contains functional groups of carboxil, hydroxil, amina, and sulfonil (Chaidir et al., 2015). Tannins, flavonoids, quinonoid, indigoid, carotenoids are some of the pigments that act as natural dyes in plants (Baliarsingh et al., 2013; Erkan et al., 2014; Mongkholrattanasit et al., 2011). Tannin may functionate as a mordant as well. The presence of tannin improved the color tone of woolen fabrics (Gumrukcu and Ozgur, 2011).

Some natural dyes contain tannins in different concentrations. Gambier which is very well known for textile dye has a tannin content of $28.51 \%$ (Sofyan and Failisnur, 2017). The pomegranate peel includes high tannin containing material that can be used for natural dyes with a content about 19\% (Adeel et al., 2009; Tiwari et al., 2010). Differences in tannin levels in plants will affect the results and quality of the resulting dye.

Jengkol pod extract was acidic with a low $\mathrm{pH}$ of 4.87. The remaining dye extract had a $\mathrm{pH}$ of 4.97 . The increase in $\mathrm{pH}$ is due to the effect of colored fabrics. The difference in $\mathrm{pH}$ conditions in each treatment is due to the nature of the mordant used. The use of an alkaline $\mathrm{CaO}$ mordant had a $\mathrm{pH}$ between $10.77-12.75$, mordant $\mathrm{Al}_{2}\left(\mathrm{SO}_{4}\right)_{3}$ was acidic with a $\mathrm{pH}$ between 3.13-3.69, and mordant $\mathrm{FeSO}_{4}$ was highly acidic with a $\mathrm{pH}$ between 2.64-2.85.

Some studies reported that the darkness and color strength are strongly affected by the $\mathrm{pH}$ of the dye. Dyeing with young teak leaves using aluminum sulfate mordant obtained a purple color with the highest color darkness at $\mathrm{pH} 10$. Gray color obtained in ferrous sulfate mordant with the highest color darkness value at $\mathrm{pH} 5$ (Rosyida and Achadi, 2014). The stability of teak leaf extract color is influenced by the change of $\mathrm{pH}$. The blue color will be produced at high $\mathrm{pH}$, then violet, and will change to red at low pH (Harmayani et al., 2013). The $\mathrm{pH}$ variation from 1 to 7 causes a discoloration of dark red, a brownish red to brown in coloration with a rosella flower (Hibiscus sabdariffa) extract (Hayati et al., 2012). An increase in $\mathrm{pH}$ will lead to an increase in the value of $\mathrm{K} / \mathrm{S}$ in dyeing with saffron flower (Kamel et al., 2009). 


\subsection{Result of dyeing and color intensity}

The results of cotton dyeing with different mordant types and methods are shown in Table 2. From the coloring results on cotton fabrics, the use of mordant type and method affected the color of the fabric. The effect can be seen from the difference of the darkness and strength of the fabric color. The control treatment dyed with jengkol pod extract without mordant produced a brown color. This color was visually similar to mordant $\mathrm{Al}_{2}\left(\mathrm{SO}_{4}\right)_{3}$ and $\mathrm{CaO}$. The use of mordant $\mathrm{FeSO}_{4}$ produced a cloth with a greenish brown color. This color difference is due to the reaction of different metal cations in the mordant namely $\mathrm{Fe}^{2+}$ in $\mathrm{FeSO}_{4}, \mathrm{Al}^{3+}$ in $\mathrm{Al}_{2}\left(\mathrm{SO}_{4}\right)_{3}$, and $\mathrm{Ca}^{2+}$ in $\mathrm{CaO}$ with dye anion and fiber anion. The chemical bond that formed between the ions and dyes which is diffused into the fiber had a difference complexes strong bond. The complex mechanism of the cellulose fibers and dyes with ion metal is represented in Figure 1.

Some studies of natural dyes research reported a similar color with this research. One of them is the color produced by the use of natural dye gambier (Uncaria gambir Roxb). (Sofyan and Failisnur, 2016) reported that the color produced in dyeing with gambier using $\mathrm{CaO}$ mordant was brown to reddish brown with the value of Lab coordinate for cotton fabrics is $31.27,7.64$, and 10.15 respectively. The use of mordant $\mathrm{FeSO}_{4}$ produced a green color with the value of Lab coordinate for cotton fabrics is $42.05,4.06$, and 5.97 respectively. The measurement was in the same wavelength $400 \mathrm{~nm}$. Coloring with palm shells and cocoa shells provided a reddish brown color with lime mordant and greenish black with ferrous sulfate mordant (Pujilestari et al., 2016).

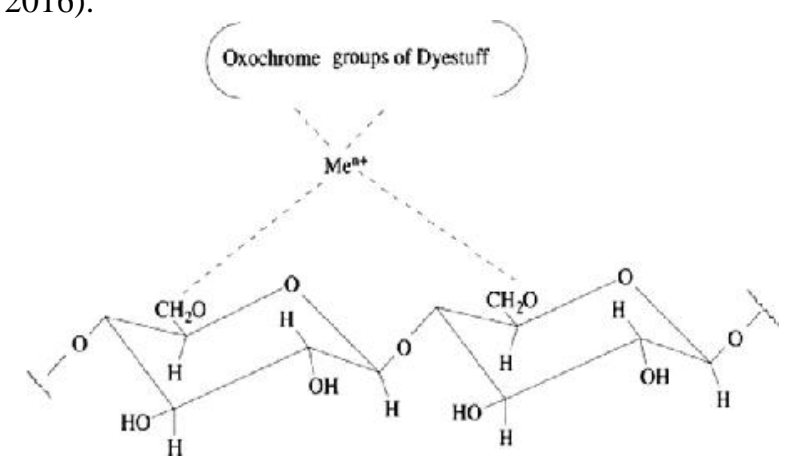

Figure 1. The complex mechanism of cellulose fibers and dyes with ion metal (Erkan et al., 2014).

It can be seen visually the color difference between one treatment with others. The $\mathrm{K} / \mathrm{S}$ value was used to see the color intensity of each treatment at the same wavelength $400 \mathrm{~nm}$. The greater the $\mathrm{K} / \mathrm{S}$ value the greater the color darkness as shown in Figure 2.

In addition to using the $\mathrm{K} / \mathrm{S}$ value, a color difference value $(\mathrm{dE})$ was used to see the color absorption. This value was obtained by comparing each sample of fabric with a control fabric (without mordant) The larger the $\mathrm{dE}$ value the more the color absorption and the color difference that occurs between the sample and control fabrics is greater. The $\mathrm{dE}$ value of each treatment is shown in Table 3.

Table 2

Dyeing result of fabric using jengkol pod.

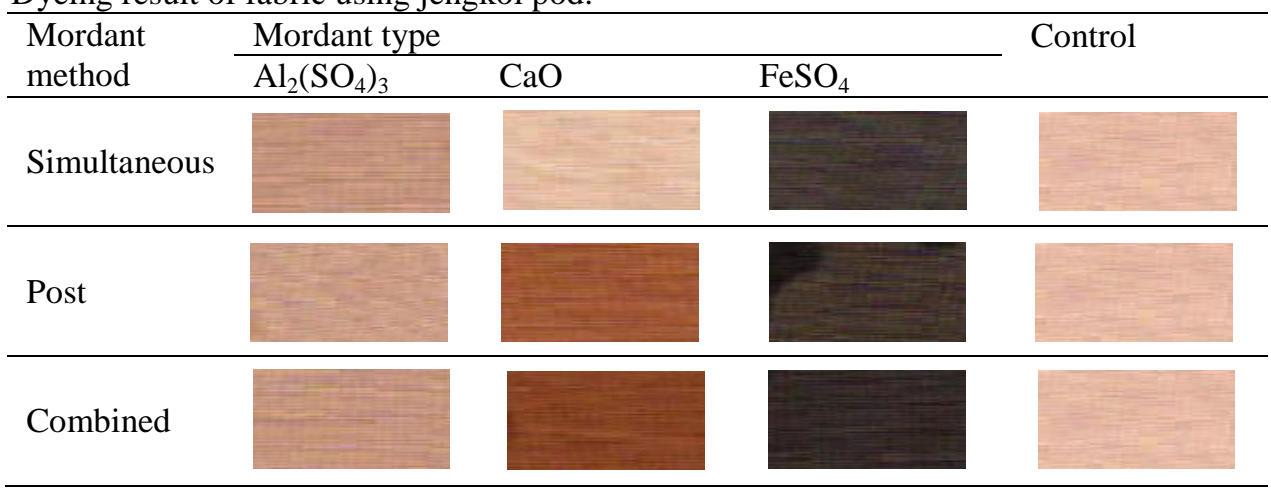

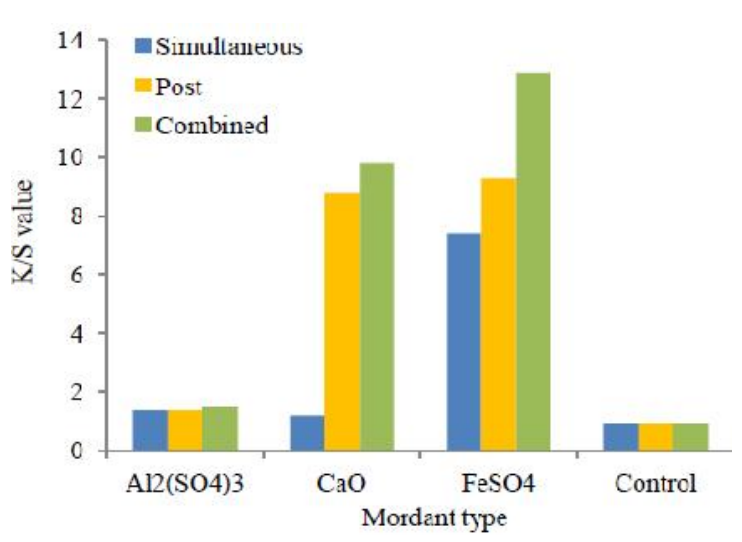

Figure 2. K/S value of each treatment at the wavelength $400 \mathrm{~nm}$
Table 3. Color difference (dE) value of each treatment

\begin{tabular}{llll}
\hline \multirow{2}{*}{$\begin{array}{l}\text { Type of } \\
\text { mordant }\end{array}$} & \multicolumn{3}{l}{ Method of mordant } \\
\cline { 2 - 4 } & Simultaneous & Post & Combined \\
\hline $\mathrm{Al}_{2}\left(\mathrm{SO}_{4}\right)_{3}$ & 8.13 & 7.00 & 9.80 \\
$\mathrm{CaO}$ & 2.15 & 29.96 & 35.23 \\
$\mathrm{FeSO}_{4}$ & 39.73 & 41.30 & 45.93 \\
\hline
\end{tabular}

Control fabric which was through the mordant process had an average K/S value of 0.927 . The all treatments, simultaneous, post, and combined methods can increase the intensity of the color compared with no mordant addition. When viewed from the type of mordant, The $\mathrm{Al}_{2}\left(\mathrm{SO}_{4}\right)_{3}$ mordant had the smallest color darkness with the smallest value of $\mathrm{K} / \mathrm{S}$ average compared with other treatments. The K/S value of this 
treatment was $1.340 ; 1.351$; and 1.499 for simultaneous, post, and combined methods respectively. This K/S value is almost close to the control value as shown in Figure 1. The small difference in K/S values between the simultaneous method and control is also seen from the coloring results in Table 2. The colors produced with $\mathrm{Al}_{2}\left(\mathrm{SO}_{4}\right)_{3}$ mordant are visually only slightly different from the control colors.

Some studies on natural dyes using $\mathrm{Al}_{2}\left(\mathrm{SO}_{4}\right)_{3}$ mordant also reported the same thing with the results of this study. The reaction of the complexity between aluminum metal and dye is weaker than other metals (Failisnur et al., 2017; Failisnur and Sofyan, 2016; Khattak et al., 2014). The color intensity is strongly associated with the reaction that occurs between the dyeing molecules and the positively charged metal mordant (Wanyama et al., 2010).

The highest of color darkness and difference were obtained in the treatment using $\mathrm{FeSO}_{4}$ mordant. It was obtained by all mordant methods, simultaneous, post, or combined. In Figures 1 and Table 3 can be seen that the K/S value using $\mathrm{FeSO}_{4}$ mordant was 7.405; 9.270; 12.868 and the $\mathrm{dE}$ value was $39.73 ; 41.30 ; 45.93$ for each mordant method.

Treatment of mordant method affected the coloring result on cotton fabric. Each method gives a different effect. Among the mordant methods, the lowest color darkness was produced on the fabric by the simultaneous mordant method. In this method, the dye extract solution and mordant are in one medium. The dyeing and mordant process were done simultaneously. This causes the absorption of dye does not take place in maximum. This condition appears to be very influential in dyeing using $\mathrm{CaO}$ mordant. The difference in $\mathrm{K} / \mathrm{S}$ values between simultaneous and combined methods is very far. The K/S value using $\mathrm{CaO}$ mordant was 1.173 ; 8.810; 12.868 consecutively for simultaneous, post, and combined methods.

The highest color darkness for each type of mordant was obtained in the treatment using the combined mordant method. In this method, dyeing and mordant is done alternately. First of all, it was dyed with dyestuff extract and then was mordant. This was done as much as three replications. The result was the dyestuff absorbed more. Repeated mordant processes will cause the dyes that interact with the metal ions are also higher. This result in the color of the fabric on the combined mordant method was darker than the single mordant.

The use of $\mathrm{CaO}$ mordant with the simultaneous method resulted in the lowest color darkness of 1.173 and 2.15 (Figures 1 and 2). This value is almost the same as the value of K/S control and can be seen from the color generated visually is almost similar (Table 2). This suggests that the use of $\mathrm{CaO}$ mordant is less suitable to be done using the simultaneous method. However, with the post and combined method, the resulting of high color darkness and difference.

The colors produced by each treatment visually can be seen in Table 2. Both type and mordant method affected the color direction. To see the difference and brightness of color, it was then analyzed using color coordinate or CIE Lab color space method. The measurements results of $\mathrm{L}^{*}, \mathrm{a}^{*}$, and $\mathrm{b}^{*}$ value are shown in Table 4.

The result of using $\mathrm{Al}_{2}\left(\mathrm{SO}_{4}\right)_{3}$ mordant showed that the color strength of the sample fabric is almost the same as the control fabric. The mordant process used $\mathrm{CaO}$ showed that the color strength of the sample fabric tends to lead to the yellow color. This can be seen from the ratio of $b$ and a values in the test data. The ratio between the yellow and red was greater in the samples of fabrics with $\mathrm{CaO}$ mordant.

The values of $a^{*}$ and $b^{*}$ are smaller than the other samples in samples processed with the $\mathrm{FeSO}_{4}$ mordant. The smaller the values of $a^{*}$ and $b^{*}$, the closer the color coordinate position to the center which means that the color is darker, leading to black if accompanied by a small $\mathrm{L}^{*}$ value or lead to a gray color. In the $\mathrm{FeSO}_{4}$ sample, the change in the color strength becomes dark (greenish grey) occurs because the dye interacts with $\mathrm{Fe}^{2+}$ ions. Fe metals have a greenish-specific color and affect the color change in the dyeing fabric.

Table 4

Measuring result of color intensity and color direction of fabric.

\begin{tabular}{lllll}
\multicolumn{1}{l}{$\begin{array}{l}\text { Treatment } \\
\text { Mordant } \\
\text { type }\end{array}$} & $\begin{array}{l}\text { Mordant } \\
\text { method }\end{array}$ & \multicolumn{3}{c}{ Measuring result } \\
\cline { 3 - 5 } & & $\mathrm{L}^{*}$ & $\mathrm{a}^{*}$ & $\mathrm{~b}^{*}$ \\
\hline $\mathrm{Al}_{2}\left(\mathrm{SO}_{4}\right)_{3}$ & Simultaneous & 67.73 & 8.26 & 14.82 \\
& Post & 68.72 & 8.01 & 13.95 \\
& Combined & 66.2 & 8.67 & 15.61 \\
\hline $\mathrm{CaO}$ & Simultaneous & 74.92 & 7.14 & 13.95 \\
& Post & 51.52 & 15.2 & 29.47 \\
& Combined & 44.48 & 15.46 & 27.94 \\
\hline FeSO & Simultaneous & 37.15 & 1.61 & 5.76 \\
& Post & 35.05 & 2.6 & 7.87 \\
& Combined & 30.91 & 2.05 & 4.53 \\
\hline Control & & 75.58 & 8.82 & 12.79 \\
\hline
\end{tabular}

\subsection{The color fastness to washing}

The results of the color fastness to washing are seen from the color change of the sample before and after washing. The value is in a range from 2 to 4 (scale 1 to 5 ) as shown in Table 5. Some studies give a criteria to the scale of the color fastness namely 1 (very poor), 2 (poor), 3 (fair), 4 (good), and 5 (very good) (Khattak et al., 2014; Mongkholrattanasit et al., 2011; Pujilestari et al., 2016). The lower of the color change value indicates the more dye which faded from the fabrics. Treatment of $\mathrm{CaO}$ mordant type with simultaneous and combined methods had a color fastness to washing better than other treatments fair to good (3-4). This result is in line with the research of natural dyes using gambier and secang (Caesalpinia sappan) wood on cotton and rayon fabric using calcium oxide and ferrous sulfate with color fastness to washing was 3-4 (Failisnur et al., 2017). 
Table 5

Analysis result of color fastness to washing $40^{\circ} \mathrm{C}$.

\begin{tabular}{|c|c|c|c|c|c|c|c|c|}
\hline \multirow{3}{*}{$\begin{array}{l}\text { Treatment } \\
\text { Mordant } \\
\text { type }\end{array}$} & \multirow{3}{*}{$\begin{array}{l}\text { Mordant } \\
\text { method }\end{array}$} & \multicolumn{7}{|c|}{ Analysis result } \\
\hline & & \multirow{2}{*}{$\begin{array}{l}\text { Color } \\
\text { change }\end{array}$} & \multicolumn{6}{|c|}{ Color staining } \\
\hline & & & Acetate & Cotton & Polyamide & Polyester & Acrylate & Wool \\
\hline \multirow{3}{*}{$\mathrm{Al}_{2}\left(\mathrm{SO}_{4}\right)_{3}$} & Simultaneous & $2-3$ & $4-5$ & $4-5$ & $4-5$ & $4-5$ & $4-5$ & $4-5$ \\
\hline & Post & $2-3$ & $4-5$ & $4-5$ & 4 & $4-5$ & $4-5$ & $4-5$ \\
\hline & Combined & $2-3$ & $4-5$ & 4 & $4-5$ & $4-5$ & $4-5$ & $4-5$ \\
\hline \multirow{3}{*}{$\mathrm{CaO}$} & Simultaneous & $3-4$ & $4-5$ & $4-5$ & $4-5$ & $4-5$ & $4-5$ & $4-5$ \\
\hline & Post & 3 & $4-5$ & $4-5$ & 4 & $4-5$ & $4-5$ & $4-5$ \\
\hline & Combined & $3-4$ & $4-5$ & $4-5$ & $4-5$ & $4-5$ & $4-5$ & $4-5$ \\
\hline \multirow{3}{*}{$\mathrm{FeSO}_{4}$} & Simultaneous & $2-3$ & $4-5$ & $4-5$ & $4-5$ & $4-5$ & $4-5$ & $4-5$ \\
\hline & Post & $2-3$ & $4-5$ & $4-5$ & $4-5$ & $4-5$ & $4-5$ & $4-5$ \\
\hline & Combined & $2-3$ & $4-5$ & $4-5$ & $4-5$ & $4-5$ & $4-5$ & $4-5$ \\
\hline Control & & $3-4$ & $4-5$ & $4-5$ & 4 & $4-5$ & $4-5$ & $4-5$ \\
\hline
\end{tabular}

The color-fastness of the control fabric is the same as the $\mathrm{CaO}$ mordant treatment by the simultaneous and combined method (3-4). This means that the control fabric without mordant already has a fair to good color fastness to washing. This indicates that the dye bond with the fabric fibers without mordant is strong enough, but the color darkness is low because without mordant only a few dyes can react with the fiber. Mordant can form coordinate bonds that can increase absorption of dyes (Ahmad et al., 2011; Uddin, 2014). The low color fastness in mordant-treated fabrics is due to the mordant metal bonding and the dye in the fabric fibers is less strong and unstable. Another possibility was the dyestuff is only absorbed on the fiber surface rather than on the fiber core, so it is easily removed during washing.

Treatment of type and method mordant has no significant effect on the properties of color-fastness. This result is almost similar to the study of pomegranate dyeing (Punica granatum) that reported the use of ferrous sulfate and aluminum sulfate mordant with pre and post mordant methods can increase color intensity, but not improve the color fastness (Das et al., 2006).

Some natural dye research states that mordant treatment not only adds the variation and intensity of the resulting color but also adds the color-fastness of the fabric. The interaction between mordant, dye, and fiber will lead to the formation of complexes which result in a higher of absorption and color stability so that the releases dye when washing is smaller (Rather et al., 2016).

The color staining value in most treatments was 4-5 (scale 1 to 5). Some treatments had a value of 4 . This value indicates a good color fastness that means the dyestuff only slightly dyes the other fibers. This is because the dyestuff and the wash solution phase have a very small affinity to the fibers (acetate, cotton, polyamide, polyester, acrylate, and wool). Consequently, the color staining value will be high (4-5).

\subsection{The color fastness to acidic and alkaline sweat}

The color fastness to acidic and alkaline sweat is performed in Tables 6 and 7. The color change values vary of 2-3, 3, and 4. From the type and treatment of mordant, the process with $\mathrm{Al}_{2}\left(\mathrm{SO}_{4}\right)_{3}$ mordant using the post and combined method have the best value that is good (4). This value is equal to control fabric value. In general, these results are almost identical to the results of color fastness to washing with the control values which are better. This condition shows that the treatment of mordant type and method does not make the characteristics of color fastness to acidic sweat better but the mordant type treatment produces more diverse color (Table 2).

Table 6

Analysis result of color fastness to acidic sweat.

\begin{tabular}{|c|c|c|c|c|c|c|c|c|}
\hline \multicolumn{2}{|l|}{ Treatment } & \multicolumn{7}{|c|}{ Analysis result } \\
\hline \multirow{2}{*}{ Mordant type } & \multirow{2}{*}{$\begin{array}{l}\text { Mordant } \\
\text { method }\end{array}$} & \multirow{2}{*}{$\begin{array}{l}\text { Color } \\
\text { change }\end{array}$} & \multicolumn{6}{|c|}{ Color staining } \\
\hline & & & Acetate & Cotton & Polyamide & Polyester & Acrylate & Wool \\
\hline \multirow{3}{*}{$\mathrm{Al}_{2}\left(\mathrm{SO}_{4}\right)_{3}$} & Simultaneous & $2-3$ & $4-5$ & $4-5$ & $4-5$ & $4-5$ & $4-5$ & $4-5$ \\
\hline & Post & 4 & $4-5$ & $4-5$ & $4-5$ & $4-5$ & $4-5$ & $4-5$ \\
\hline & Combined & 4 & $4-5$ & $4-5$ & 4 & $4-5$ & $4-5$ & $4-5$ \\
\hline \multirow{3}{*}{$\mathrm{CaO}$} & Simultaneous & 3 & $4-5$ & $4-5$ & 4 & $4-5$ & $4-5$ & $4-5$ \\
\hline & Post & $2-3$ & $4-5$ & $4-5$ & $4-5$ & $4-5$ & $4-5$ & $4-5$ \\
\hline & Combined & 3 & $4-5$ & $4-5$ & $4-5$ & $4-5$ & $4-5$ & $4-5$ \\
\hline \multirow{3}{*}{$\mathrm{FeSO}_{4}$} & Simultaneous & $2-3$ & $4-5$ & $4-5$ & $4-5$ & $4-5$ & $4-5$ & $4-5$ \\
\hline & Post & $2-3$ & $4-5$ & $4-5$ & $4-5$ & $4-5$ & $4-5$ & $4-5$ \\
\hline & Combined & 3 & $4-5$ & $4-5$ & $4-5$ & $4-5$ & $4-5$ & $4-5$ \\
\hline Control & & 4 & $4-5$ & $4-5$ & 4 & $4-5$ & $4-5$ & $4-5$ \\
\hline
\end{tabular}


Table 7

Analysis result of color fastness to alkaline sweat.

\begin{tabular}{|c|c|c|c|c|c|c|c|c|}
\hline \multicolumn{2}{|l|}{ Treatment } & \multicolumn{7}{|c|}{ Analysis result } \\
\hline \multirow{2}{*}{ Mordant type } & \multirow{2}{*}{$\begin{array}{l}\text { Mordant } \\
\text { method }\end{array}$} & \multirow{2}{*}{$\begin{array}{l}\text { Color } \\
\text { change }\end{array}$} & \multicolumn{6}{|c|}{ Color staining } \\
\hline & & & Acetate & Cotton & Polyamide & Polyester & Acrylate & Wool \\
\hline \multirow{3}{*}{$\mathrm{Al}_{2}\left(\mathrm{SO}_{4}\right)_{3}$} & Simultaneous & $2-3$ & $4-5$ & $4-5$ & $4-5$ & $4-5$ & $4-5$ & $4-5$ \\
\hline & Post & 3 & $4-5$ & $4-5$ & $4-5$ & $4-5$ & $4-5$ & $4-5$ \\
\hline & Combined & 3 & $4-5$ & $4-5$ & 4 & $4-5$ & $4-5$ & $4-5$ \\
\hline \multirow{3}{*}{$\mathrm{CaO}$} & Simultaneous & 3 & $4-5$ & $4-5$ & $4-5$ & $4-5$ & $4-5$ & $4-5$ \\
\hline & Post & 3 & $4-5$ & 4 & $4-5$ & $4-5$ & $4-5$ & $4-5$ \\
\hline & Combined & 4 & $4-5$ & 4 & $4-5$ & $4-5$ & $4-5$ & $4-5$ \\
\hline \multirow{3}{*}{$\mathrm{FeSO}_{4}$} & Simultaneous & $2-3$ & $4-5$ & $4-5$ & 4 & $4-5$ & $4-5$ & $4-5$ \\
\hline & Post & $2-3$ & $4-5$ & $4-5$ & $4-5$ & $4-5$ & $4-5$ & $4-5$ \\
\hline & Combined & 3 & $4-5$ & $4-5$ & $4-5$ & $4-5$ & $4-5$ & $4-5$ \\
\hline Control & & $3-4$ & $4-5$ & $4-5$ & $4-5$ & $4-5$ & $4-5$ & $4-5$ \\
\hline
\end{tabular}

The results of the color change in the color fastness to alkaline sweat were also not significantly different. Resistance to the color change of the best samples was good (4). It was obtained in the treatment using $\mathrm{CaO}$ mordant with the combined method. The other treatment test result was smaller than the control. It also shows that the treatment of mordant type and method does not make the resistance of color change to the alkaline sweat better. Type of one's sweat either acidic or alkaline will greatly determine the color-fastness of the fabric.

The resistance to color staining of samples on other fabrics toward acidic and alkaline sweat was 4-5 in average (scale 1 to 5). It shows the color staining of this fabric against other fibers is very small. Treatment of mordant type and method has no significant effect on color staining values.

\subsection{The color fastness to light and rubbing}

One of the characteristics to see the quality of the dyeing is by measurements its color fastness to light and rubbing. The results of color fastness to light and rubbing (dry and wet cotton) are shown in Table 8. In terms of mordant type and method, the use of $\mathrm{CaO}$ mordant with post and combined methods generated the best light fastness to light with a value of 4-5 (good to very good). This result is better than the controlled fabric treatment (without mordant) with a value of 3-4 (fair to good). The $\mathrm{Al}_{2}\left(\mathrm{SO}_{4}\right)_{3}$ and $\mathrm{FeSO}_{4}$ mordant with simultaneous, post, and combined methods have the same values as the control fabric. This indicates that the treatment does not have a significant effect on improving the color fastness to light.

Natural dyes generally have a low color-fastness to light with a value below 3 . The best result was obtained in this research 4-5. This value was a good result to excellent. The complex formed between mordant and dye will protect the chromophore from photolytic degradation (Khattak et al., 2014).

The color fastness to rubbing (dry and wet cotton) was good to very good (4-5) in averages for all mordant types and methods. This value was almost equal to the value of the control fabric. These results indicate that the mordant type and method treatments do not have a significant effect on the color fastness to rubbing. The non-mordant colored fabrics (control) have given a good to an excellent value for color fastness to rubbing.

Table 8

Color fastness to light and rubbing.

\begin{tabular}{|c|c|c|c|c|}
\hline \multicolumn{2}{|c|}{ Treatment } & \multirow{2}{*}{$\begin{array}{l}\text { Color } \\
\text { fastness to } \\
\text { light }\end{array}$} & \multicolumn{2}{|c|}{$\begin{array}{l}\text { Color fastness } \\
\text { to rubbing }\end{array}$} \\
\hline $\begin{array}{l}\text { Mordant } \\
\text { type }\end{array}$ & $\begin{array}{l}\text { Mordant } \\
\text { method }\end{array}$ & & $\begin{array}{l}\text { Dry } \\
\text { cotton }\end{array}$ & $\begin{array}{l}\text { Wet } \\
\text { cotton }\end{array}$ \\
\hline \multirow{3}{*}{$\mathrm{Al}_{2}\left(\mathrm{SO}_{4}\right)_{3}$} & Simultaneous & $3-4$ & $4-5$ & $4-5$ \\
\hline & Post & $3-4$ & $4-5$ & $4-5$ \\
\hline & Combined & 3 & $4-5$ & $4-5$ \\
\hline \multirow{3}{*}{$\mathrm{CaO}$} & Simultaneous & $3-4$ & $4-5$ & $4-5$ \\
\hline & Post & $4-5$ & $4-5$ & $4-5$ \\
\hline & Combined & $4-5$ & $4-5$ & $4-5$ \\
\hline \multirow{3}{*}{$\mathrm{FeSO}_{4}$} & Simultaneous & $3-4$ & $4-5$ & $4-5$ \\
\hline & Post & $3-4$ & $4-5$ & 4 \\
\hline & Combined & $3-4$ & $4-5$ & 4 \\
\hline Control & & $3-4$ & $4-5$ & $4-5$ \\
\hline
\end{tabular}

\section{Conclusions}

The results show that the type of mordant affected the intensity and color strength of the fabric. The use of $\mathrm{FeSO}_{4}$ mordant produced the highest color darkness and difference for all mordant methods which can be seen from the value of K/S and $\mathrm{dE}$. From the treatment of mordant type and method, the lowest color darkness was obtained in $\mathrm{CaO}$ mordant with the simultaneous method.

Treatment of mordant type and method has no significant effect on color fastness to washing, acidic and alkaline sweat, light, and rubbing. The colored fabrics have the same color-fastness as the controls on average, moreover some of them were lower than control. The treatment which has better color-fastness than control was the color fastness to light using $\mathrm{CaO}$ mordant with post and combined method and color fastness to alkaline sweat using $\mathrm{CaO}$ mordant with combined method. The average of color staining test has a value of 4-5 for all treatments.

\section{Acknowledgment}

Our best gratitude is adressed to Baristand Industri Padang for funding this research activity through DIPA budget, it is also adressed to Marlusi, Sulastri, and 
Prasemiati Ningsih for assisting in the implementation of this research.

\section{References}

Adeel, S., Ali, S., Bhatti, I.A., Zsila, F., 2009. Dyeing of cotton fabric using pomegranate (Punica granatum) aqueous extract. Asian J. Chem. 21, 3493-3499.

Ahmad, W.Y.W., Rahim, R., Ahmad, M.R., Kadir, M.I.A., Misnon, M.I., 2011. The application of gluta aptera wood (rengas) as natural dye on silk and cotton fabrics. Univers. J. Environ. Res. Technol. 1, $545-551$.

Azima, F., Nazir, N., Sari, N.P., 2017. The making and characterization of husk jengkol's activated carbon as adsorbent. Int. J. Adv. Sci. Eng. Inf. Technol. 7, 916921.

Baliarsingh, S., Jena, J., Das, T., Das, N.B., 2013. Role of cationic and anionic surfactants in textile dyeing with naturaldyes extracted from waste plant materials and their potentialantimicrobial properties. Ind. Crops Prod. 50, 618-624.

Barceloux, D.G., 2009. Djenkol bean [Archidendron jiringa (Jack) I. C. Nielsen]. Med. Toxicol. Nat. Subst. Foods, Fungi, Med. Herbs, Toxic Plants, Venom. Anim. 55, 361-362. doi:10.1016/j/ disamonth.2009.03.005

Chaidir, Z., Hasanah, Q., Zein, R., 2015. Penyerapan ion logam $\mathrm{Cr}(\mathrm{III})$ dan $\mathrm{Cr}(\mathrm{VI})$ dalam larutan menggunakan kulit buah jengkol (Pithecellobium jiringa (JACK) PRAIN.). J. Ris. Kim. 8, 189-199.

Das, D., Battacharya, S.C., Maulik, S.R., 2006. Dyeing of wool and silk with Punica granatum. Indian $\mathbf{J}$. Fibre Text. Res. 3, 559-564.

Directorate General of Holticulture, 2015. Production statistic of horticulture year 2014 [WWW Document]. Minist. Agric.

Erkan, G., Sengul, K., Kaya, S., 2014. Dyeing of white and indigo dyed cotton fabrics with Mimosa tenuiflora extract. J. Saudi Chem. Soc. 18, 139-148. doi:10.1016/j.jscs.2011.06.001

Failisnur, F., Sofyan, S., 2016. Pengaruh suhu dan lama pencelupan benang katun pada pewarnaan alami dengan ekstrak gambir (Uncaria gambir Roxb). J. Litbang Ind. 6, 25-37. doi:http://dx.doi.org/ 10.24960/jli.v6i1.716.25-37

Failisnur, F., Sofyan, S., 2014. Sifat tahan luntur dan intensitas warna kain sutera dengan pewarna alam gambir (Uncaria gambir Roxb) pada kondisi pencelupan dan jenis fiksator yang berbeda. J. Litbang Ind. 4, 1-8. doi:http://dx.doi.org/ 10.24960/jli.v4i1.634.1-8

Failisnur, F., Sofyan, S., Kumar, R., 2017. Efek pemordanan terhadap pewarnaan menggunakan kombinasi limbah cair gambir dan ekstrak kayu secang pada kain rayon dan katun. J. Litbang Indsutri 7, 93-100. doi:http://dx.doi.org/ 10.24960/jli.v7i2.3541.93-100

Gumrukcu, G., Ozgur, M.U., 2011. Effect of tannic acid and metal salts on dyeing of woolen fabrics with red onion ( Alliumcepa L.). Asian J. Chem. 23, 14591466.
Harmayani, E., Ayatullah, M.S., Hastuti, P., 2013. Ekstraksi, karakterisasi, dan pemanfaatan daun jati (Tectona grandis) sebagai pewarna merah alami dalam pengolahan kerupuk aci. J. Penelit. dan Pengemb. DIY2 V, 96-108.

Hayati, E.., U.S., B., R., H., 2012. Konsentrasi total senyawa antosianin ekstrak kelopak bunga rosella (Hibiscus sabdariffa L.): pengaruh temperatur dan pH. J. Kim. 6, 138-147.

Kamel, M.M., Helmy, H.M., Hawary, N.S. El, 2009. Some studies on dyeing properties of cotton fabrics with crocus sativus (saffron) (flowers) using an ultrasonic method. AUTEX Res. J. 9, 29-35.

Khasnabis, J., Rai, C., Roy, A., 2015. Determination of tannin content by titrimetric method from different types of tea. J. Chem. Pharm. Res. 7, 238-241.

Khattak, S.P., Rafique, S., Hussain, T., Ahmad, B., 2014. Optimization of fastness and tensile properties of cotton fabric dyed with natural extracts of Marigold flower (Tagetes erecta) by pad-steam method. Life Sci. J. 11, 52-60.

Kumaresan, M., 2014. Comparison of fastness properties of dyed cotton fabric with eco-friendly natural dyes obtained from achras sapota and cordia. J. Environ. Nanotechnol. 3, 60-66. doi:10.13074/jent. 2013.12.132060

Moiz, A., Ahmed, M.A., Kausar, N., Ahmed, K., Sohail, M., 2010. Study the effect of metal ion on wool fabric dyeing with tea as natural dye. J. Saudi Chem. Soc. 14, 69-76. doi:10.1016/j.jscs.2009.12.011

Mongkholrattanasit, R., Kryštůfek, J., Wiener, J., Vikova, M., 2011. Dyeing, fastness, and UV protection properties of silk and wool fabrics dyed with eucalyptus leaf extract by the exhaustion process. Fibres Text. East. Eur. 19, 94-99.

Muthukumarasamy, R., Nabilah, F.B.M.F., Rosli, N.B., Asmaq, N.B.M., Ilyana, A.B.A.B., Radhakrishnan, S., 2017. Effects of selected mordants on the application of natural dye extracted from the pods of pithecellobium jiringa seeds. Indo Am. J. Pharm. Sci. 4, 4655-4661. doi:http://doi.org/10.5281/zenodo. 1123320

Pujilestari, T., Farida, F., Pristiwati, E., Atika, V., Haerudin, A., 2016. Pemanfaatan zat warna alam dari limbah perkebunan kelapa sawit dan kakao sebagai bahan pewarna kain batik. Din. Kerajinan dan Batik 33, 1-8. doi:http://dx.doi.org/10.22322/dkb. v33i1.1119

Rather, L.J., Islam, S.U., Shabbir, M., Bukhari, M.N., Shahid, M., Khan, M.A., Mohammad, F., 2016. Ecological dyeing of woolen yarn with Adhatoda vasica natural dye in the presence of biomordants as an alternative copartner to metal mordants. J. Environ. Chem. Eng. 4, 3041-3049. doi:10.1016/J.JECE.2016.06.019

Rosyida, A., Achadi, W.D., 2014. Pemanfaatan daun jati muda untuk pewarnaan kain kapas pada suhu kamar. Arena Tekst. 29, 115-124.

Samanta, A.K., Agarwal, P., 2009. Application of natural dyes on textiles. Indian J. Fibre Text. Res. 34, 384-399. 
Selvam, R.M., Athinarayanan, G., Nanthini, A.U.R., Singh, A.J.A.R., Kalirajan, K., Mosae, S.P., 2015. Extraction of natural dyes from Curcuma longa, Trigonella foenum graecum and Nerium oleander, plants and their application in antimicrobial fabric. Ind. Crops Prod. 70, 84-90. doi:https://doi.org/10.1016/j.indcrop.2015.03.008

Sofyan, S., Failisnur, F., 2017. Reuse of liquid waste from textile dyeing with natural dyes gambier (Uncaria gambir Roxb.) for cotton yarn dyeing. ARPN J. Eng. Appl. Sci. 12, 5313-5318.

Sofyan, S., Failisnur, F., 2016. Gambir (Uncaria gambir Roxb) sebagai pewarna alam kain batik sutera, katun, dan rayon. J. Litbang Indsutri 6, 89-98. doi:http://dx.doi.org/10.24960/jli.v6i2.1721.89-98

Sofyan, S., Failisnur, F., Sy, S., 2015. Pengaruh perlakuan limbah dan jenis mordan kapur, tawas, dan tunjung terhadap mutu pewarnaan kain sutera dan katun menggunakan limbah cair gambir (Uncaria gambir Roxb). J. Litbang Indsutri 5, 79-89. doi:http://dx.doi.org/10.24960/jli.v5i2.668.79-89

Syahputra, A., Eni, W., Teja, D.S., 2009. Pemanfaatan ekstrak kulit jengkol (Pithecollobium jiringa), daun pacar air (Impatiens balsamina) dan kulit rambutan (Nephelium lappaceum) sebagai pewarna alami tekstil. Fak. MIPA, Univ. Bengkulu.
Tiwari, H.C., Singh, P., Mishra, P.K., Srivastava, P., 2010. Evaluation of various techniques for extraction of natural colorants from pomegranate rind ultrasound and enzyme assisted extraction. Indian $\mathrm{J}$. Fibre Text. Res. 35, 272-276.

Uddin, M.G., 2014. Effects of different mordants on silk fabric dyed with onion outer skin extracts. Hindawi Publ. Corp. J. Text. 2014, 1-8. doi:http://dx.doi.org/10.1155/2014/405626

Wanyama, P.A.G., Kiremire, B.T., Ogwok, P., Murumu, J.S., 2010. The effect of different mordants on strength and stability of colour produced from selected dye-yielding plants in Uganda. Int. Arch. Appl. Sci. Technol. 1, 81-92.

Yusuf, M., Mohammad, F., Shabbir, M., 2017. Ecofriendly and effective dyeing of wool with anthraquinone colorants extracted from Rubia cordifolia roots: Optimization, colorimetric and fastness assay. J. King Saud Univ. - Sci. 29, 137144. doi:10.1016/j.jksus.2016.06.005 